\title{
The Distribution of Tubercle Bacilli in Estrogen-Treated Mice
}

Stimulation, by estrogens, of phagocytosis has been demonstrated by studying the blood clearance of various inert particles, such as colloidal carbon or trypan blue, after i.v. injection ${ }^{1,2}$. Proliferation of the reticuloendothelial system of the liver has been found following estrogen administration $\mathbf{1 , 3}$, but no information is available either on the uniformity of this effect with other phagocytized particles, or on the role of other organs in it. In the present work, the effect of estradiol benzoate on the phagocytosis in mice has been studied using s.c. injection of tritium-labelled tubercle bacilli.

Female mice from the inbred strain CBA and from the random bred albino strain NMRI were used. The initial weights of the mice were $20-22 \mathrm{~g}$; the mean weight of the groups to be compared with each other, were adjusted to be equal, to within $0.1 \mathrm{~g}$. Estradiol benzoate (17 $\beta$ estradiol-3-benzoate) was dissolved in sesame oil, $5.0 \mathrm{mg} /$ $\mathrm{ml}$, and administered s.c. in a dose of $0.5 \mathrm{mg} / \mathrm{mouse} / \mathrm{in}-$ jection. The estrogen was injected twice, 6 days and 2 days before the injection of the bacteria. This dosage, calculated per day, equals that used in the previous studies ${ }^{2,4}$. The control animals were treated in a similar manner with sesame oil.

The Mycobacterium tuberculosis strain H37Rv was grown on Finlayson's egg medium ${ }^{5}$ to which was added $50 \mu \mathrm{c} / \mathrm{ml}$ of $\mathrm{D}$-glucose- $6-\mathrm{H}^{3}(500 \mathrm{mc} / \mathrm{m} M$, The Radiochemical Centre, Amersham). After 6 weeks' growth at $37^{\circ} \mathrm{C}$, the bacteria were killed by autoclaving, harvested from the surface of the medium, washed with saline until no radioactivity was found in the supernatant, and suspended in saline. The number of bacteria was determined using a counting chamber. The bacterial preparations were kept at $4{ }^{\circ} \mathrm{C}$ and were used within 4 weeks. During that time they were found to be stable as tested by the bacterial count and the radioactivity in the supernatant. After the injection of labelled bacteria, the mice were killed at appropriate intervals with a light gas, and specimens were immediately taken from the spleen, kidney (a half kidney, cut transverse on the pelvis), liver, lung, and blood. The blood was collected from the peritoneal cavity just after cutting the renal veins. The specimens were weighed in counting vials (the sample size varied from $40-200 \mathrm{mg}$ ), digested, and counted as described earlier ${ }^{6}$.

$8.4 \times 10^{7}$ labelled tubercle bacilli $\left(116 \times 10^{3} \mathrm{dpm}\right)$ were injected, in a volume $0.1 \mathrm{ml}$, s.c. to CBA mice, under the dorsal skin. The results (Figure) reveal significantly lower bacterial content in the blood of estrogen-treated mice than in the controls. The difference is to be seen in the samples taken 15-60 min after the bacterial injection. Similar differences, although not as clearly seen, are revealed by counts from lung, liver, and spleen, but not from kidneys. In the samples taken $2 \mathrm{~h}$ or more after the injection, no uniform differences can be found. In the blood and lung, the maximum radioactivity is found 15 to $30 \mathrm{~min}$ after the bacterial injection. In the liver and spleen, the maximum is not as definite, and occurs later.

The experiments were repeated using mice of the NMRI strain. The results were very similar to those obtained with the CBA strain, revealing the same effect of the estrogen, and the same differences in the organ distribution as in the Figure.

These results with killed tubercle bacilli are contradictory to the earlier observations indicating estrogeninduced stimulation of phagocytosis ${ }^{1,2}$. It is likely that the effect of estrogens on phagocytosis is dependent, not directly on the kind of injected particles, but on the presence of antibodies against the particles. Phagocytosis

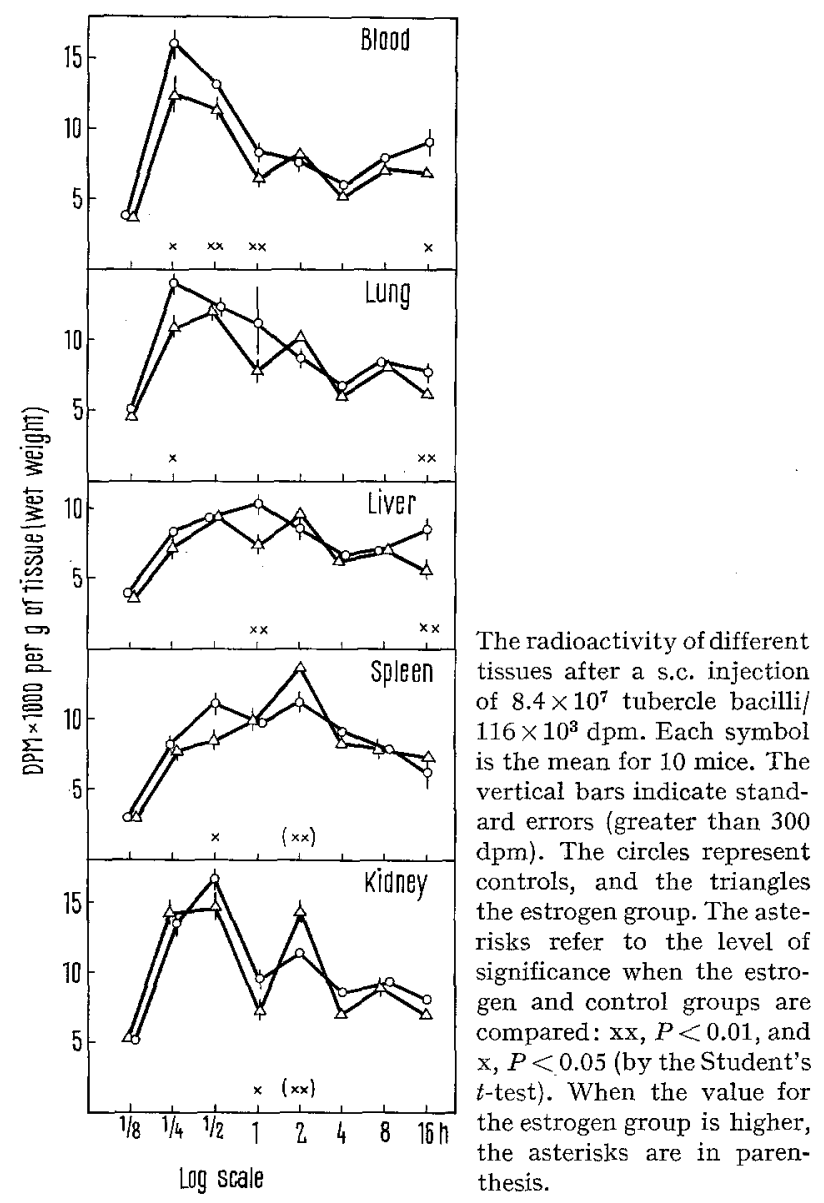

is greatly influenced by antibodies 7,8 , and estrogens may suppress antibody synthesis and immunological activity ${ }^{9-11}$.

Zusammentassung. Estradiol-benzoat verursacht bei der Maus eine Abnahme der Phagozytose und der Ausbreitung in die Gewebe von tritiummarkierten s.c. injizierten Tuberkelbazillen.

Department of Medical Microbiology,

P. Tolvanen ${ }^{12}$

University of Turku

Turku 3 (Finland), 16 July 1969.

${ }^{1}$ L. S. Kelly, E. L. Dobson, C. R. Finney and J. D. Hirsch, Am. J. Physiol. 198, 1134 (1960).

2 T. Nicol, D. L. J. Bilbey, L. M. Charles, J. L. Cordingley and B. Vernon-Roberts, J. Endrocrin. 30, 277 (1964).

3 M. Mosinger, Bull. Acad. Méd. 130, 487 (1946).

${ }^{4}$ P. Tolvanen, Annls Univ. Turku Ser. A II, 35, 1 (1966).

5 M. K. Finlayson, J. Path. Bact. 58, 88 (1946).

6 L. Salminen, H. Järvinen and P. Torvanen, Acta ophthal. 47 , 115 (1969).

7 B. Benacerraf, M. M. Sebestyen and S. Schlossman, J. exp. Med. 110, 27 (1959)

8 D. E. Rogers, Bact. Rev. 24, 50 (1960).

P. Tolvanen, Ann. Med. exp. Fenn. 45, 152 (1967).

10 P. Tolvanen, K. Mä̈̈ttä, R. Suolanen and R. Tykkylätnen, Med. Pharmac. exp. 17, 33 (1967).

11 R. L. Simmons, A. L. Price and A. J. Ozerkis, Am. J. Obstet. Gynec. 100, 908 (1968)

12 Supported by a grant from the Tampere Tuberculosis Foundation. 